Ann. Génét. Sél. anim., 1976, 8 (4), 493-499.

\title{
ARTHROGRYPOSIS IN CHAROLAIS CATTLE A STUDY ON GENE PENETRANCE ( ${ }^{1}$ )
}

\author{
L. A. GOONEWARDENE and R. T. BERG
}

\author{
Department of Animal Science \\ The University of Alberta \\ (Canada)
}

\section{SUMMARY}

SAP (Syndrome of Arthrogryposis and Palatoschisis) is a congenital abnormality affecting Charolais cattle and is conditioned by an autosomal recessive gene. Among pure Charolais animals in France the gene penetrance seems low while among Charolais crosses in Canada penetrance is almost complete.

In a study of 3 case histories in Canada at least five Charolais bulls that may be homozygous and recessive for SAP have been identified. Such bulls show zero penetrance which is probably brought about by the selection and accumulation of modifier genes through an evolationary process. Charolais crossbreds however have nearly complete penetrance probably due to an incomplete complement of the necessary modifiers which are able to supress or alter the gene penetrance.

The presence of homozygous recessives normal overlap which had not been individually demonstrated in French herds does result in the low penetrance of the SAP gene, according the estimations done in such Charolais populations.

\section{INTRODUCTION}

A Syndrome of Arthrogryposis and Palatoschisis affecting Charolais cattle (SAP) has been reported in several countries and an annotated bibliography has been prepared by LAUVERGNE and FAUCON (1976). In general the defect is characterised by crippling of the fore and/or hind limbs and is often associated with a cleft palate.

Studies conducted by LAUVERGNE and BLIN (I968), LAUVERGNE (I975), NAWROT (r973) and BERG and GoONEWARDENE (1974) have established a genetic basis for SAP, the gene in question being of an autosomal recessive type.

(2) From MSc. thesis of Goonewardrne (r974). Extracts presented at the 56th Annual Conference of the Agricultural Institute of Canada (AIC), Halifax, Nova Scotia, 1976. 
In studies conducted on pure Charolais populations in France, the penetrance of the gene appears to be around o.Io and o.I4 for males and females respectively (LAUvergne, r972). Among Charolais crossbreds in Canadian herds the gene penetrance seems to be almost complete (NAWROT, I973; BERG and GoONEWARDENE, r974).

The purpose of this paper was to study the differences in gene penetrance among pure and crossbred Charolais animals by studying three case histories from the beef industry in Canada.

\section{MATERIALS AND METHODS}

The data for the study came from two sources namely, the Experimental Beef Breeding Station at Kinsella, Alberta maintained by the University of Alberta and from the records of the Canadian Charolais Association.

At the Experimental Station up to 197533 calves have been identified as having SAP and 28 carrier females recognized. The dams which are proven carriers together with those suspected of carrying the recessive gene, based on their pedigrees are being maintained in a herd referred to as the crippled herd. The dams in the crippled herd were derived from a hybrid line established in I960 using three foundation breeds namely, Angus, Galloway and Charolais, the latter being introduced by bulls both by A.I. and natural service.

Two cases from the beef industry that will be discussed in this report come from the breeding records maintained by the Canadian Charolais Association.

\section{OBSFRVED CASFS AND THEIR INTERPRETATION}

Case (I).

In 1965 at the Experimental Beef Breeding Station at Kinsella, one sire, a purebred Charolais bull was mated in the same year to four of his half blood Charolais daughters the sire himself being proven a carrier of SAP. Of the four daughters one did not settle but the three that did conceive produced crippled progeny (fig. I). As the defective gene is not of a dominant type the case could be explained in one of two ways. Assuming that the original sire was a carrier of the defective gene, i.e. heterozygous, when bred to the non Charolais dams only $50 \%$ of the progeny would be heterozygous carriers. If the daughters were bred back to him in a second generation, assuming that half were heterozygous, $12.5 \%$ of all calves would be expected to be defective. Although numbers are small the probability of the observed occurrence under the hypothesis is only 0.002 and a second and more probable hypothesis could be considered. If the original sire was a homozygous recessive carrier of the defective gene then all his progeny would be carriers, i.e. heterozygous. Crossing back to his daughters will then result in expectation of $50 \%$ of the progeny being defective, and a probability of 0.125 of three daughters from three matings being defective. Thus, the hypothesis that the sire was a homozygous carrier with zero penetrance is more compatible with the observations of an above normal frequency of defectives in the second generation. Phenotypically the sire appeared normal; on the other hand his grand progeny which were $75 \%$ Charolais showed complete penetrance. 

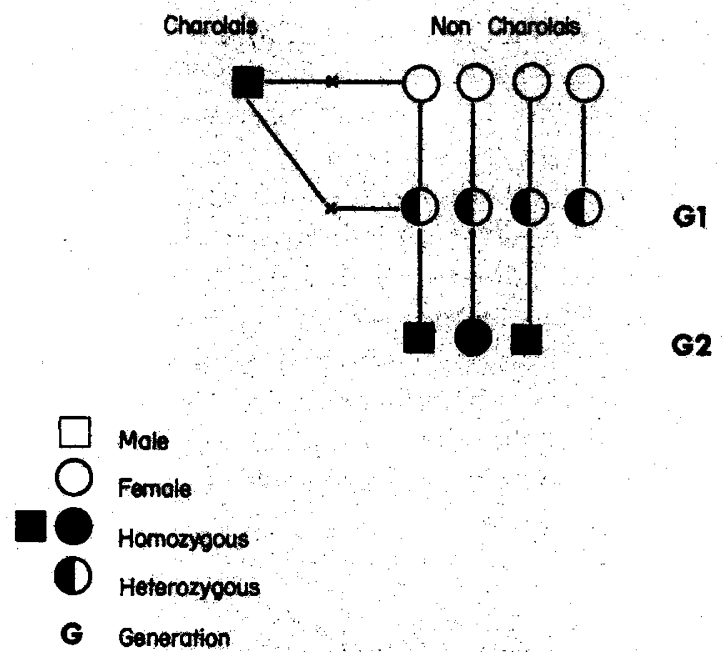

Fig. t. - Case no (I) - 1966, Kinsella, one pure Charolais size bred to fow of his owow datighters

Fig. I. - Cas n' 1 , a Kinsella un 1965 un male Charolais pur race croise a 4 de ses filles

Case (II).

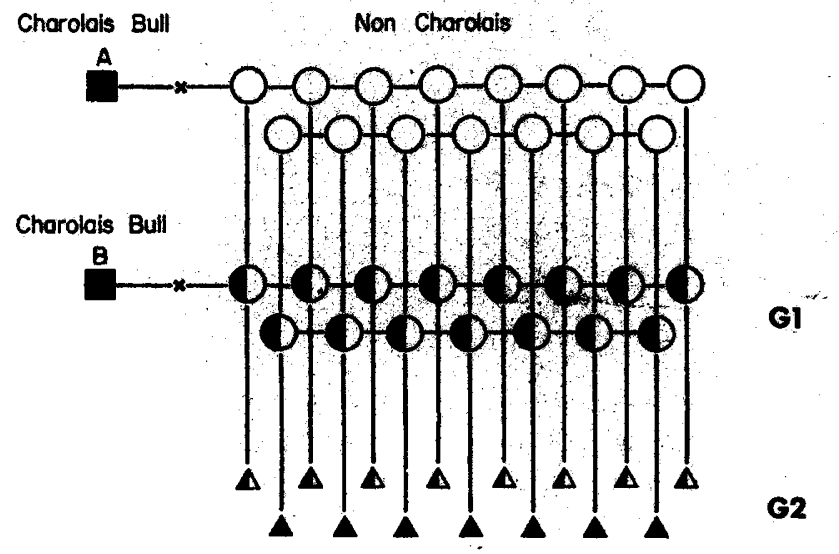

\footnotetext{
$\square$ Male

Fermole

$\triangle$ Sex unidentified

A Homozygous

DA Heterozygous

G Generotion
}

FIG. 2. - Case $\mathrm{n}^{\circ}$ (II) : Fifteen non Charolais dams bred to twoo Charolais sires $A$ and $B$ in subsequent years, where eight normal and seven $S A P$ calves were observed.

Frg. 2. - Cas $\mathrm{n}^{\circ} \mathrm{II}$ : quinse mìres non Charolaises accouplees par la suite d 2 males Charolais $A$ et $B$ donnent huit veaux normaux et sept $S A P$ 
In I968 a pure Charolais bull (A) was bred to a group of non-Charolais females, mainly Shorthorns, the resulting progeny being half blood Charolais (fig. 2). In I97I a second Charolais bull (B) was bred to fifteen of the daughters of bull (A) along with other yearling heifers. In the spring of 1972 a total of thirty two calves were obtained through the use of bull (B) and fifteen of them were from the daughters of bull (A). Of the fifteen calves, eight were normal and seven showed SAP. Analysing the records it seems unlikely that sires (A) and (B) were merely heterozygous carriers of the defective gene and if this be the case the expectation in the second generation would be about 2-3 defective calves. A second possibility that could account for the higher number of defective calves observed would be that both sires were homozygous carriers of SAP and if this were the case a near I:I ratio for crippled and normal progeny would be expected in the second generation which is very close to the observed ratio.

Case (III).

The third example comes from a case encountered by a cattleman in Saskatchewan. Thirty heifers were purchased by him, the heifers being from three pure Charolais bulls referenced (X), (Y) and (Z) (fig. 3). All heifers were either Charolais $\times$ Hereford

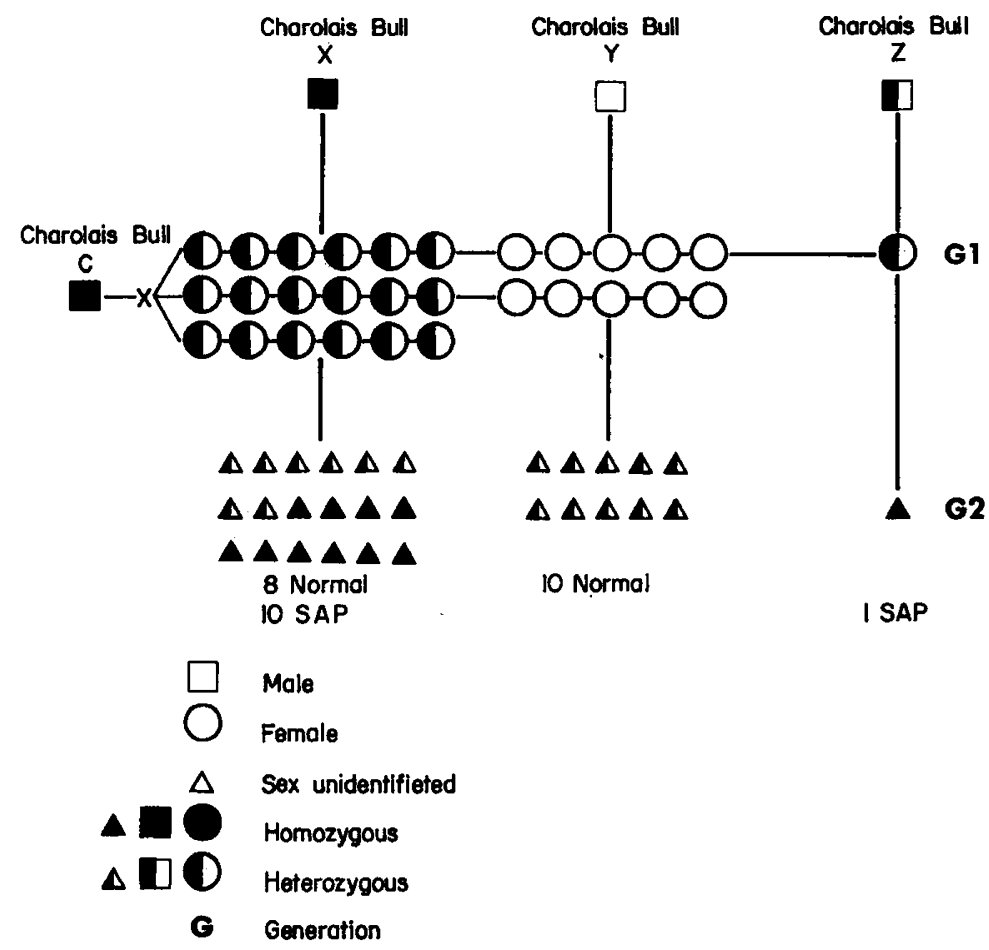

FrG. 3. - Case no (III) : The daughters of 3 Charolais bulls $x, y$ and $z$ bred to a single Charolais bull $c$. Ten $S A P$ calves produced from the daughters of $x$, nowe from the daughters of $y$ and one $S A P$ calf from the daughter of $z$.

FIG. 3. - Cas $n^{\circ}$ III : Les filles de 3 taureaux Charolais $x, y$ et $z$ accouplées au male Charolais c. Les filles de $x$ produsisent 10 SAP, les filles de $y$ aucun et celles de $z$ un seul. 
crosses or three quarter Charolats, one quarter Hereford crosses. Of the thirty heifers eighteen were from $(\mathrm{X})$, ten from $(\mathrm{X})$ and one from $(2)$. As the pedigree information on the last heifer was incomplete it was left out of the study. In I 969 the twenty nine heifers were exposed to breeding to a single Charolais bull (C) and eleven defective calves were observed, ten of them being from daughters of sire $(X)$ and one from the daughter of sire $(Z)$. No defective progeny were produced from the daughters of $(\mathbf{Y})$. The case shows that sire $(\mathbf{X})$ passed down the defective gene to at least ten out of eighteen of his daughters. It is also evident that the gene was introduced into the heifers through sire $(X)$ as all his mates were Herefords. The most probable hypothesis is that sires $(\mathrm{X})$ and $(\mathrm{C})$ were homozygous recessive carriers of SAP.

From the three cases studied it seems evident that homozygous sires do exist and are able to live and reproduce normally. The defective gene in the homozygous state shows no apparent penetrance although bull (B) referred to in case (II) has shown signs of crippling with age. The crossbred progeny having the recessive genes in the homozygous state do show almost complete penetrance.

\section{DISCUSSION}

The sires falling into this classification of homozygous normal overlaps were pure Charolais while those showing full penetrance of the defective gene were Charolais crossbreds. The expressivity of the gene varies considerably and some SAP calves have been observed with mild symptoms such as slight flexion and/or over extension of the fore and/or hind limbs (GrRoun and GUEGUEN, I973), while others show extreme rigidity in the joints with severely reduced muscle tissue and abnormal knee caps and could be classified as being grossly affected. A third category of abnormalities occurs where limb defects associated with a cleft palate have also been observed but there seems to be no apparent association between the severity of the limb defect and the observance of a cleft palate (LAUVERGNE, I975).

Modifier genes play an important role in determining phenotypic expressions of characters. The tultimate phenotypic expression of any character depends on the actions of primary or major genes, interactions among major and modifier genes and the environment. Thus the phenotypic expression depends on the entire genome and environment rather than just a single pair of recessive genes as has been often visualized. Genes code for amino acid sequences or polypeptides and the products of gene action are proteins and enzymes. Each phenotypic character expressed arises due to a series of biochemical processes mediated by enzymes with specific properties conferred by the sequence of base pairs in the DNA. Modifier genes are translated and transcribed in the same way as major genes and in general play a very significant role in altering gene expression by fitting into certain biochemical pathways. Modifier genes may produce an end product that inhibits or augments the production of a particular protein or enzyme or that may provide a more or less efficient alternate pathway for an intermediate reaction in a basic biochemical pathway thereby modifying the phenotype.

The normal overlap homozygous recessive carriers of SAP probably have the required complement of modifier genes to correct the abnormality by fitting into 
specific biochemical pathways or providing alternate pathways, eventually modulating the phenotype. In the supression of the recessive genotype seen to occur $\mathbf{n}$ the pure Charolais, the entire genetic system would have evolved the ability to overcome the defect as a direct result of natural selection of modifier genes and this could account for the very low penetrance. Among Charolais crossbreds penetrance seems to be almost complete as they apparently do not have the correct complement of modifier genes to alter or completely supress the defect.

The evolution of decreasing penetrance by natural selection is similar to the phenomenon of " Evolution of Dominance " theorized by FisterR (I928 a, I928 b) and reviewed by SHEPPARD and FORD (Ig66). It carries the concept one stage further as the recessive homozygote is moved toward a normal phenotype, whereas FisHer's phenomenon deals with the gradual modification of the heterozygote to a dominant phenotype.

The study clearly establishes that pure Charolais sires that are homozygous recessive do exist. The reason for the low penetrance that LAUVERGNE (1975) observed with respect to SAP in French Charolais herds may well be due to an overlap of homozygous and heterozygous carriers in his herds, the homozygotes being recognized as carriers rather than showing the defect. Individual bulls that are homozygous and recessive for SAP have as yet not been identified in France but there existence was anticipated (see LAUVERGNE's, fig. I, r974).

In French Charolais herds modifier genes that supress the SAP syndrome may be fixed to such an extent that the penetrance is kept at a very low level.

\section{CONCLUSIONS}

Evidence for the existence of homozygous recessive carrier sires are presented and at least three cases have been observed. The study confirms that the penetrance of the SAP gene type appears to differ in relation to the genotype, where full penetrance is observed among Charolais crossbreds and almost no penetrance is observed among certain pure Charolais cattle.

Regu pour publication en décembre 1976.

\section{ACKNOWLEDGEMENTS}

The authors wish to thank the Canadian Chavolais Association for providing some of the data for this paper.

\section{RÉSUMÉ}

I'ARTHROGRYPOSE EN RACE CHAROLAISE, UNE ÉTUDE DE PÉNÉTRANCE DU GÈNE

Le Syndrome d'Arthrogrypose et de Palatoschisis (SAP) est une anomalie congénitale qui frappe le bétail Charolais et qui dépend d'un gène autosomal récessif. En France et en race pure la pénétrance chez les homozygotes semble basse alors qu'au Canada parmi les animaux croisés, elle est presque totale. 
L'étude de trois cas a permis d'identifier au Canada au moins cinq taureaux de service homozygotes pour le gène donnant SAP. La pénétrance du gèrie chez ces animaux est nulle et cela est da probablement à la sélection qui a entraíné l'accumulation de gènes modificateurs. La pénétrance totale observée chez les croisés est due à un manque de ces modificateurs nécessaires pour supprimer ou modifier la pénétrance.

Jusqu'à présent aucun homozygote récessif porteur sain n'avait encore été identifié dans les élevages français bien que les estimations de la pénétrance laissaient prévoir leur existence.

\section{REFERENCES}

Berg R. T., Goonewardene I. A., 1974. Arthrogryposis or crippled calf condition" in cattle. 53rd Annual Feeders' Day Report. Dept. An. Sci., Univ. of Alta, 22-27.

Fisher R. A., rg28 a. The possible modification of the response of the wild type to recurrent mutations. Amer. Nat., 62, II5-126.

Fisher R. A., I928 b. Two further notes on the origin of dominance. Amer. Nat., 68, $571-574$.

Grroud A., Gueguen L., r973. Sur les Arthromyodysplasies chez le veau. Bull. Acad. vet., 96, 443446.

LAUVERGNe J. J., I972. Heretidary determinism of Arthrogryposis with Palatoschisis Syndrome in Charolais cattle. Conference given at the Beef Cattle Research Ranch, university of Alberta, Kinsella Alberta, no published.

LAUVERGNe J. J., r974. Etude des genes à effets visibles à partir des données de testage des taureaux sur leur descencance. I er Congr. mond. Génét. Appl. elevage, 1, 47-55.

LAUVERGNe, J. J., I975. État présent des connaissances sur le syndrome d'arthrogrypose et de palatoschisis (SAP) dans le bétail Charolais de France. Anm. Genát. Sel. anim., 7, 321-330.

LaUvergne J. J. and Blin P. C., rg68. Hereditary determinism of cleft palate associated with ankylosis of limbs in Charolais cattle. XII Int. Conf. Génét., 1, 277.

LaUvergne J. J., Faucon A., r976. Le syndrome d'arthrogrypose et de palatoschisis (SAP) en race bovine Charolaise. Bibliographie Annotee : 1967-1975. Ant. Genet. Sel. anim., 8, 51-70.

Nawrot P.S., 1973. Arthrogryposis a congenital defect in new born calves. MSc. Thesis. Dept. Ann. Sci., University of Saskatchewan.

Sheppard P. M. and Ford E. B., r966. Natural Selection and the Evolution of Dominance. Heredity, 81, $139-147$. 